\title{
Quieten your inner critic
}

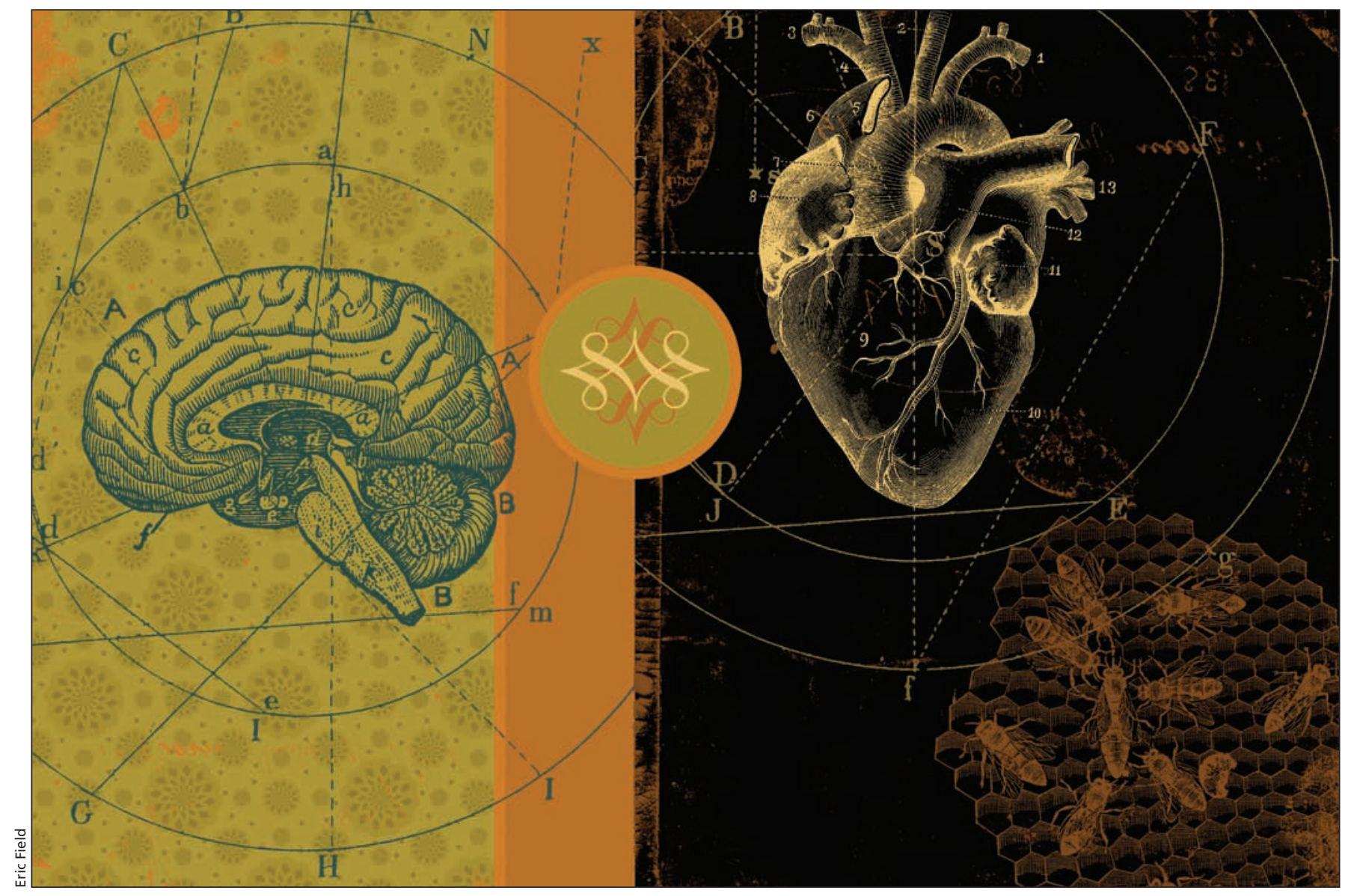

$\mathrm{T}$ here wasn't a medical humanities program at the university I attended in the 1970s, but I wish there had been. It might have prevented me from burning out in family practice - a growing problem among physicians. ${ }^{1}$ Certainly, it would have helped me to be less selfcritical, to have more self-compassion and courage and to not take it all so seriously.

When my patients used to lard and smoke themselves into an early grave, I blamed myself for being unable to stop them. I struggled in a sea of paperwork, including completing countless forms for patients. I didn't charge, for fear of giving offence, but then beat myself up for being a pushover. And, I took myself and everything I did, far too seriously.

I came by low self-esteem honestly, having spent the best part of my childhood in an orphanage where I learned to act nicely and take care of others. Memorizing information and regurgitating it on demand got me into and through medical school. University is called alma mater, sweet mother, where bright young people receive both an education and a second chance at nurturing. And, with luck, they learn to mimic honey bees, who gather nectar for the common good of their hive.

A medical school humanities program takes this concept of community a step further by providing a shared community of creativity, which in turn nurtures participants' courage, compassion and sense of playfulness.

It begins with the courage to reach into oneself and offer to the world a creative work that may be criticized or praised. The latter is particularly problematic; most people dismiss a compliment — "Oh, it's nothing" having been persuaded as children that compliments lead to swollen heads. But when you are able to receive positive feedback for your creation, it goes to the heart and quietens your inner critical voice. In short, it raises self-esteem

I recall a time in fourth year when I admitted a little boy whose thumb had been severed by a lawn mower. The 
critical period had passed and there was no hope of reattaching it. I felt dreadful and returned to my tiny on-call cubicle where I cried a bit, wolfed down Mars bars and despised myself for my professional weakness.

Had I been encouraged to write about my experience, I would have written about more than a tiny thumb in a plastic bag. My story would have included a description of the hospital, which was built beside a brewery that at one time supplied patients and, most likely, staff with their daily tipple. The hospital smelled of hops and had a grassy inner quadrangle on the inside; outside, it was surrounded by huge wrought iron gates. The porter, whose lodge was just inside the gates, chimed a brass bell every time a surgeon entered; the sound would reverberate through the wards ... and so on.

Taking the narrative stance and assuming authority for my experience would have allowed me to shift my focus outward, away from my negative feelings and into a community that understood. A compassionate and appreciative hearing would have helped further quieten my inner critic. Free from its harping, I could have more clearly identified and separated my responsibilities as a clerk from my responsibility to myself. After work, I might have eschewed the Mars bars and gone and fed the ducks instead.

Acquiring the skills that allow you to have

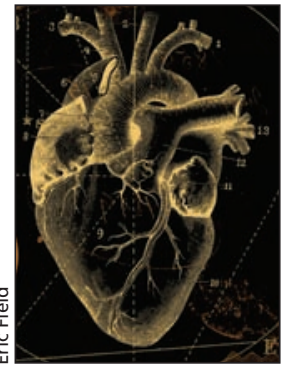
courage, self-

compassion and the ability to take yourself lightly may be what is needed to prevent graduates from burning out in practice.

Hippocrates, the father of medicine and our Western humanities, was known for his compassionate treatment of "melancholic" (i.e., depressed) patients. His prescriptions included gentle exercise and inspiring entertainment. Humanities programs can help fill Hippocrates' prescription by providing a nurturing environment

\section{CREATIVE WORKS}

\section{Diabetic neuropathy}

Today I traced my foot with a pencil, Took a second made my toes feel bold, essential again. So good, legs straight as pencils on 3-holed lines Everything lame, white, wrinkled sharpened, precise and callous free. I'll leave this note here for the doctor.

How amazing, this decay-subtracting stencil but alas, I can't forget the great saphenous disappointment, or the catheter in these sweatpants, forever.

To the black graphite lines in this here blood-sugar logbook, my sallow, numb calf a pales in comparison.

Tamar Rubin BSC

Class of 2011

Faculty of Medicine

University of Toronto

Toronto, Ont.

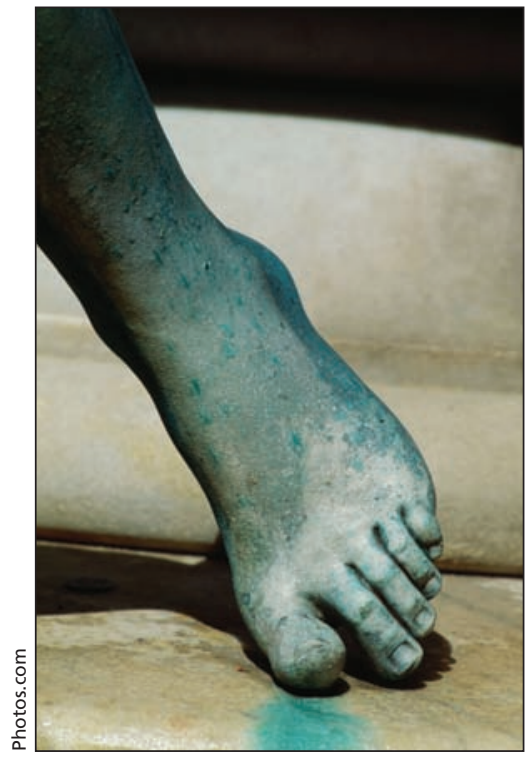

in which students can appreciate themselves as gifted, compassionate human beings first, and as physicians, second.

This may be the key to keeping future doctors happy in their practice.

\section{Julie Strong BA MD}

Family physician

Halifax, NS

\section{REFERENCE}

1. CMA Centre for Physician Health and Wellbeing. CMA study on physician burnout. Ottawa (ON): The Canadian Medical Association; 2003. Avail- able: www.cma.ca/multimedia/staticContent /HTML/N0/12/PhysicianHealth/news/pdf/Burn-out .pdf (accessed 2008 Dec. 2).

This article is an excerpt from the author's lecture, Medical Humanities: A Defence Against the Dark Arts, presented at the May 2007 International Humanities Conference in Halifax. Dr. Strong has also written a medical play and holds a baccalaureate degree in the Classics.

The author thanks Dr. Ronald Stewart, head of the Medical Humanities Program at Dalhousie University, for his encouragement. 